\title{
第一原理計算としてのエネルギー分散型蛍光X線 ファンダメンタルパラメータ法とステンレス鋼への応用
}

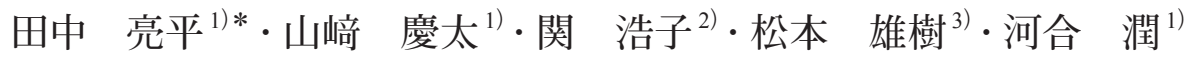

Fundamental Parameter Method for Energy Dispersive X-Ray Fluorescence and its Application to Stainless Steels as First Principles Calculation

Ryohei TAnaka, Keita Yamasaki, Hiroko Seki, Yuuki Matsumoto and Jun KaWAi

Synopsis : Energy dispersive X-ray fluorescence (ED-XRF) spectrometer was built in the laboratory with low wattage X-ray tube and silicon drift detector using a 3D printer. SUS 304 and 316L stainless steels were measured by the ED-XRF spectrometer and a sequential type inductively-coupled plasma atomic emission spectrometer (ICP-AES). The results of quantitative analysis obtained by the fundamental parameter (FP) program developed by the authors were compared with the ICP-AES results, and concluded the following three points.

(1) The FP method is a first principles method to theoretically calculate the concentration of elements using XRF. The accuracy and precision are satisfactory but inferior to the calibration curve method.

(2) The representative accuracy and precision in SUS 304 quantification are expressed as $18.3 \pm 0.08 \%$ for $\mathrm{Cr}$ and $18.1 \pm 0.01 \%$ for Ni. These values are comparable to the accuracy and precision of ED-XRF. Therefore the FP method is suitable for the ED-XRF analysis; the calibration curve method ( $\mathrm{d}_{\mathrm{j}}$ method) is highly precise and accurate, and thus suitable for wavelength dispersive (WD) XRF method.

(3) Though it is said that the FP databases should be improved in order to increase the accuracy, the FP database improvements have not been effective.

Key words: X-ray fluorescence; fundamental parameter method; quantitative analysis; energy dispersive X-ray spectrometer; first principles method.

\section{1. 緒論}

Friedman and Birks ${ }^{1)}$ が第2次世界大戦中に波長分散型 真空蛍光X線分析装置を開発し，戦後相次いで公表され た2,3)。1950年代になると, UV PVIS と並ぶカントバック の一つのユニットとしての真空蛍光X線ユニットが市販 された ${ }^{4,5)}$ 。真空蛍光 $X$ 線ユニット市販以前でも, 蛍光 $X$ 線 (XRF, X-Ray Fluorescence) 分析は共存元素によるマトリッ クス効果 (吸収効果と励起効果) のために, 試料中の元素 濃度と蛍光 $X$ 線強度が比例しないという久点があることが すでに1952年には報告されており ${ }^{6)}$, Sherman $^{7,8)}$ によって ファンダメンタルパラメータ (基礎物理定数)を用いた $\mathrm{X}$ 線強度の第一原理計算式 ${ }^{7)}$ が 1953 年には提案されていた。 Shermanの方法は当時まだ十分なデータベースが存在しな いX線吸収係数, 蛍光収率, 吸収端ジャンプ比, $\mathrm{K} \alpha: \mathrm{K} \beta$ 等 の分岐比, X線管のスペクトルというファンダメンタルパ ラメータを前提とした上で, 試料内でのX線の高次の励 起・吸収効果を計算する必要があったから, 実際に計算し
た研究者は存在せず, 手回し式の計算機しか使えない当時 としては先進的すぎて, 理論式の間違い ${ }^{9)}$ 誰も気づかな かった。真空蛍光 $X$ 線ユニットが日本の鉄鋼メーカーに導 入された 1960 年代になって, 励起・吸収効果を正しく取り 入れた理論式を Shiraiwa and Fujino ${ }^{10)}$ が発表し, 正しいファ ンダメンタルパラメータ法 (FP法) の式が得られたのは 1966年であった。

旧ソ連の Blokhin (ブラヒン) のX線データベース ${ }^{11)}$ の出 版は1982年であり, マイクロコンピュータが分析機器に導 入され始めたのも同時期であって, FP法は1980年代でも 時期尚早であった。鉄鋼標準試料を用いた検量線法 $\left(\mathrm{d}_{\mathrm{j}}\right.$ 法) がJIS G 1256 として鉄鋼メーカー各社によって制定された のは1982年であった ${ }^{12-15)}$ 。

1990年以降は，(i) エネルギー分散型蛍光X線分析装置 の普及，(ii）コンピュータの計算能力の向上，(iii）データ ベースの充実，という FP法の利用条件が整い，検量線法を 用いない第一原理計算による蛍光X線定量プログラムが 市販のXRF装置に使われるようになったが，エネルギー

2019年4月26日受付２019年5月27日受理２019年8月9日J-STAGE早期公開（Received on Apr. 26, 2019; Accepted on May 27, 2019; J-STAGE Advance published on Aug. 9, 2019)

1) 京都大学大学院工学研究科材料工学専攻 (Department of Materials Science and Engineering, Kyoto University, Yoshida-honmachi Sakyo-ku Kyoto 606-8501)

2）京都府中小企業技術センター基盤技術課（Kyoto Prefectural Technology Center for Small and Medium Enterprises）

3) 京都大学工学部物理工学科 (School of Engineering Science, Faculty of Engineering, Kyoto University)

* Corresponding author : E-mail : tanaka.ryohei.5r@kyoto-u.ac.jp

DOI : https://doi.org/10.2355/tetsutohagane.TETSU-2019-050 
分散方式XRFや2000年ごろから出現したハンドヘルド XRF装置では各種合金のライブラリースペクトルと比較 する合金の同定方法も併用され始めた。一方で，ファンダ メンタルパラメータのデータベースを改訂しようという 動きが, 2010年頃からドイツ PTB (Physikalisch-Technische Bundesanstalt) とフラン ス LNE (Laboratoire national de métrologie et d'essais) とで始まり, その後, 日本 [当初京 大の河合潤ら, 後にNIMS (National Institute for Materials Science) の桜井健次らに引継がれた）や米国 NIST (National Institute of Standards and Technology）が加わったワーク ショップが持ち回りで開催されている ${ }^{16)}$ 。このファンダメ ンタルパラメータ・ワークショップは, 周期表上の誤差の 大きな部分を再測定したり, 量子力学計算によって全元素 のファンダメンタルパラメータを改訂するなどという意欲 的なプロジェクトも含まれている。あるいはまた, Fe L $\alpha$ 線 のような軟X線領域のデータも付け加えようとする試みも ある。しかし当論文の研究成果から得られる結論は, その ようなデータベースの改良は確かに必要であろうが，その 効果は極めてわずかでしかない, というものである。FP法 のアルゴリズムは極めて強勒 (robust) であり, 現在のデー タベースは充分な正確さを有しているので, データベース に含まれる多少の不良データには影響されずに正しい結果 を算出する。

JIS G1256 ( $\mathrm{d}_{\mathrm{j}}$ 法) は検量線法であるから FP 法よりも高精 度である。そのような検量線法が鉄鋼分析には既に存在す るので, 標準試料を一切用いず, 物理定数だけから絶対定 量值を得る第一原理計算法 (FP 法) の需要があるとは言い 難い。蛍光X線分析装置の主流が, 波長分散 (WDX) 方式 からエネルギー分散 (EDX) 方式に置き換わった現在，エ ネルギー分散方式の蛍光 X線スペクトルを基にすると，第 一原理計算法がどの程度の精度や正確さを持つかを評価す ることは重要であると考えたのが, 本研究の動機である。

\section{2. 本研究の近似}

本研究では, SUS304とSUS316LのCr, Mn, Fe, Ni, Mo の 5 元素に限って（すなわち 5 元素の和が $100 \%$ になると仮 定して), 自作のエネルギー分散型蛍光X線装置で蛍光 $\mathrm{X}$ 線スペクトルを測定し, EXCELによる自作のプログラム で第一原理計算を行って, 実測スペクトルが得られるため の濃度を, 繰り返し計算によって算出した。その絶対濃度 值 (正確さ) と繰り返し測定の濃度のばらつき（分析精度） とを求めた。

なお本研究で用いた近似をまとめておくと以下の通りで ある。

（1）エネルギー分散型蛍光 X線スペクトルを用いたこと。

(2) X線管のスペクトルは，アクリル板に散乱させたコン プトン散乱線を含むスペクトルや $5 \mathrm{~cm}$ のアクリルを
透過させ減衰させたスペクトルを用いた場合を比較し たこと。どのスペクトルも EDXとした。本来, 励起X 線は, 数 $\mathrm{eV}$ の線幅の鋭い $\mathrm{K} \alpha_{1}, \mathrm{~K} \alpha_{2}, \mathrm{~K} \beta_{1,3}$ などから成る から，そうしたスペクトルをX線管のスペクトルとし て用いるべきである。一方でエネルギー分散型検出器 では特性X線は140〜300 eVという幅広のスペクトル として観測される。例えば $\mathrm{K} \alpha_{1}$ と $\mathrm{K} \alpha_{2}$ の間に, ある元素 の吸収端が存在すれば, $\mathrm{K} \alpha_{1}$ しか励起に寄与しないた め, 波長分散分光器並みの高分解能のスペクトルを励 起X線のスペクトルとして使う必要がある。しかし, $\mathrm{Cr}, \mathrm{Mn}, \mathrm{Fe}, \mathrm{Ni}, \mathrm{Mo}$ の 5 元素にはそのような関係が存 在しないので，アクリル板に散乱させた幅広のエネル ギー分散スペクトルを用いた。またX線管の特性線(た とえばロジゥム管の Rh K $\alpha$ 線) は, アクリル板を蛍光 $\mathrm{X}$ 線装置のサンプル位置に置いた散乱スペクトルを用 いることによってX線管のX線スペクトルに代用させ れば, Rh K $\alpha$ 線はコンプトンシフトしたり, 強度（散乱 断面積）が変化することになる。これらのシフトや強 度変化も無視したことになる。これ以外にも, X線管 からのX線を $5 \mathrm{~cm}$ のアクリル板を透過させて低エネル ギー成分を減衰させたスペクトルを使った場合とも比 較した。

（3）マトリックス中の強調効果としては $\mathrm{K} \alpha$ 線による高次 励起だけを考慮し, $\mathrm{K} \beta$ 線の高次励起の寄与は無視し た。ただし蛍光 $\mathrm{X}$ 線強度が $\mathrm{K} \alpha$ と $\mathrm{K} \beta$ に分岐する効果は 取り入れた。

(4) 用いた文献のファンダメンタルパラメータは波長分散 方式で測定された時代のデータを用いたので，エネル ギー分散で得られたファンダメンタルパラメータに変 換するに際して, 波長をエネルギーに変換する横軸の 変換を行った。一方, 強度については変換する場合と しない場合とを比較した。

以上のような検討を行った結果, 本論文で得られた結 論を先に述べておけば, FP法の計算においては, FPデー タベースの質は, 現時点でも充分な正確さがあり, 定量結 果にはほとんど影響せず，X線管スペクトルとして質の悪 いデータを用いても, 得られる濃度の絶対值は極めて正確 に, かつ, 高い精度で得られる, と結論できることがわかっ た。定量的な表現は結論で述べる。

\section{3. 実験方法}

エネルギー分散型蛍光 $\mathrm{X}$ 線分析における FP法の正確さ や分析精度を評価するため, 自作の蛍光 $X$ 線装置 ${ }^{17)}$ を用い て，ステンレス鋼 SUS304のスペクトルを測定し， Cr, Mn, $\mathrm{Fe}, \mathrm{Ni}, \mathrm{Mo}$ の 5 元素について, 自作の FP計算プログラム ${ }^{18}$ により濃度を算出した。また, FP計算の入力パラメータと して用いるX線管スペクトルを変化させたときの定量結果 
への影響を調べた。

Fig.1に製作した装置写真を示す。X線管や検出器の固 定には3Dプリンタを用いて製作したポリ乳酸樹脂製ホル ダー ${ }^{17)}$ を用いて，X線管一試料一検出器のなす角が $90^{\circ}$ ，そ れぞれの距離が $2 \mathrm{~cm}$ にるように配置した。X線源には 低出力X線管ULTRA-LITE MAGUNUM (Moxtek Inc., 最 大消費電力4ワット, ターゲット材：ロジウム), 検出器に はSDD (Si Drift Detector, RES-Lab社，大阪）を用いた。こ の装置を用いて, SUS304 およびSUS316Lの蛍光X線スぺ クトルを測定した。測定したスペクトルを Fig.2に示す。Cr $\mathrm{K} \beta, \mathrm{Mn} \mathrm{K} \alpha$ のエネルギーはそれぞれ $5.947 \mathrm{keV}, 5.899 \mathrm{keV}$ であり, Mn K $\alpha$ を確認することはできない。そこで, $\mathrm{Cr}$, $\mathrm{Mn}, \mathrm{Fe}, \mathrm{Ni}, \mathrm{Mo}$ 金属試料を測定しておき(Fig.3)，例 えば $\mathrm{Cr} \mathrm{K} \alpha, \mathrm{K} \beta$ 線をガウス関数でフィッティングした上

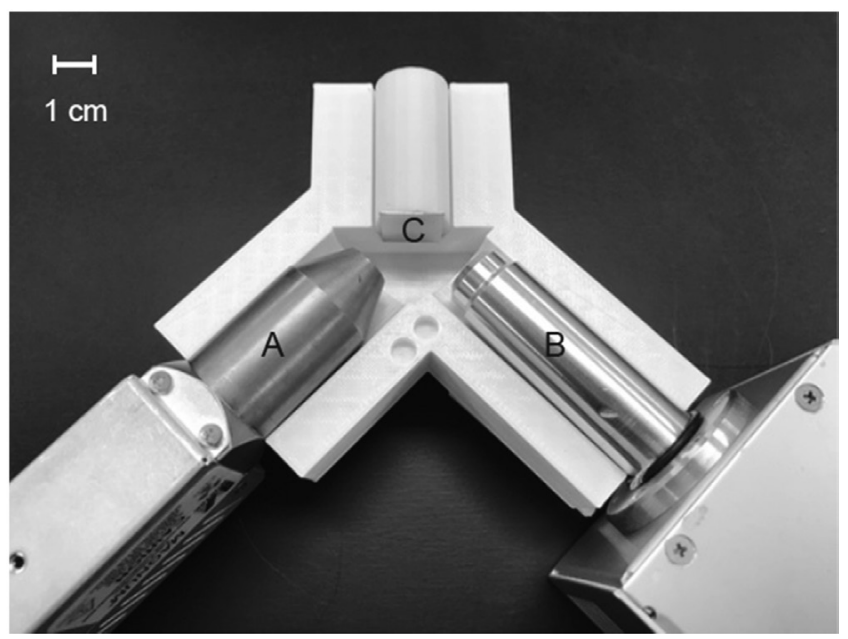

Fig. 1. Experimental setup for XRF measurement of stainless steels. (A) X-ray tube. (B) Detector. (C) sample. The holder of devices was made by using a $3 \mathrm{D}$ printer. The material of the holder was polylactic acid. The incident and takeoff angles were 45 degrees. The distance among the X-ray tube, sample, and the detector were $2 \mathrm{~cm}$.

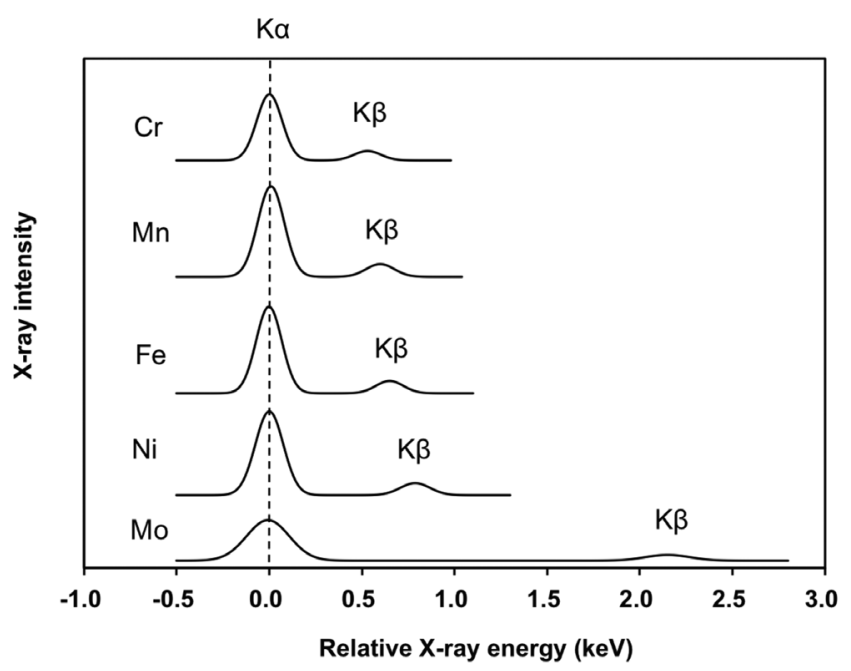

Fig. 3. XRF spectra of $\mathrm{Cr}, \mathrm{Mn}, \mathrm{Fe}, \mathrm{Ni}$, and Mo.
で, $\mathrm{Cr} \mathrm{K} \beta$ 強度比を求め, 実測スペクトルから $\mathrm{Cr} \mathrm{K} \alpha, \mathrm{K} \beta$ 線を引くことによって Mn K $\alpha$ を分離して $\mathrm{Mn}$ 強度を求め た (Fig.4)。Cr, Mn, Fe, Ni, Moの K $\alpha$ 線のエネルギーと 本研究で実測した半值幅を Table 1 に示す。特性X線の工
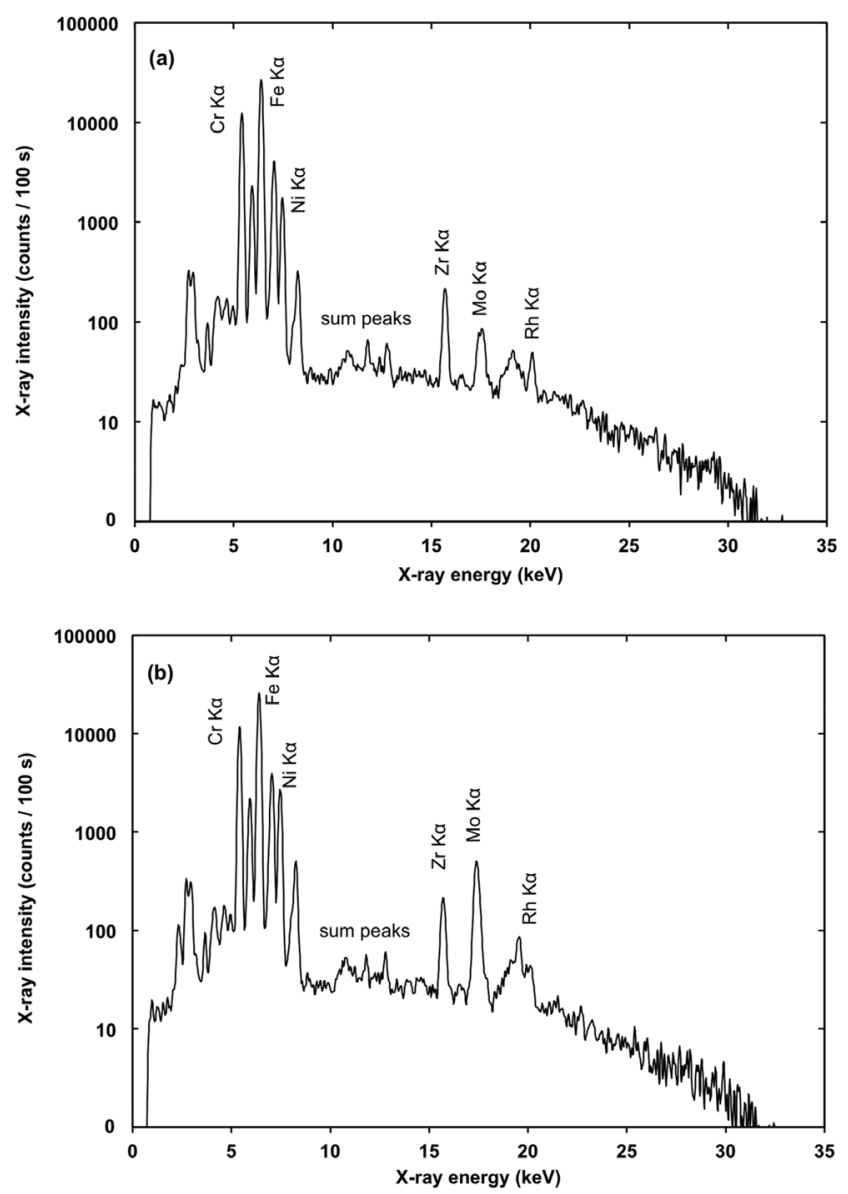

Fig. 2. XRF spectra of (a) SUS304 and (b) SUS316L. Applied voltage and current were $30 \mathrm{kV}$ and $1.5 \mu \mathrm{A}$. Measurement time was 100 seconds.

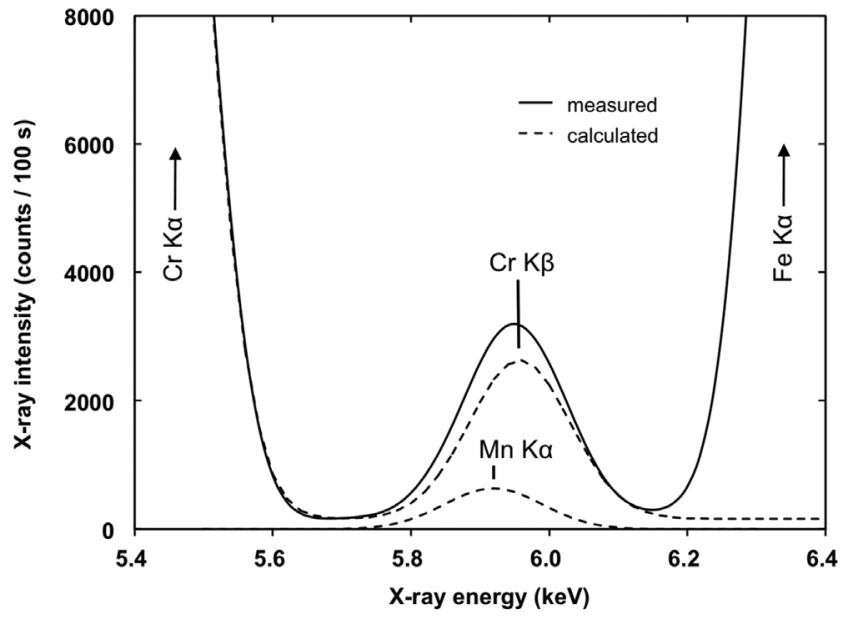

Fig. 4. Peak separation of $\mathrm{Mn} \mathrm{K} \alpha$ from XRF spectrum of a stainless steel. Solid line is measured spectrum. Broken lines are calculated spectra from the intensity ratio of $\mathrm{Cr}$ $\mathrm{K} \alpha$ to $\mathrm{K} \beta$. 
ネルギー值と半值幅とは直線関係をなす。 $\mathrm{Fe} \mathrm{K} \alpha$ 線の半值 幅が Ni K $\alpha$ 線に比べ広くなったのは, Fe K $\alpha$ 線強度が大き く, 検出器の飽和にともなうパルスの数え落としやサム ピークの発生によるピーク強度の減少が原因と考えられ る。また, 装置の感度係数を求めるため, SUS304 と近い組 成のSUS316LのXRF スペクトル測定を行った。すなわち, SUS316L を濃度既知の標準試料と見立てた上で, 未知試料 としてSUS304を定量分析したことに相当する。SUS304 お

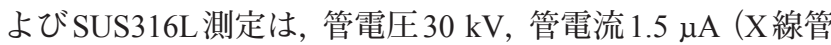
の陽極消費電力 $45 \mathrm{~mW}$ ), 測定時間 100 秒とし, 大気中で繰 り返し 3 回行った。X線管電圧はFP法ではそろえる必要が ある。入射 X線スペクトル分布を一定とするためである。 しかし本研究では, 一部 $35 \mathrm{kV}$ のX線管電圧も用いた。X線 管電流を本研究のように微弱にしても測定時間を長くすれ ば同等のスペクトルが得られると信じられているが, SDD の応答がはっきりしないので, あえて微弱なX線となる条 件で実験した。SDDは 100 万 $\mathrm{cps}$ まで対応するとされてい るが, 後述するようにデジタル回路はブラックボックス化 しているからである。

SUS304中にCr, Mn, Fe, Ni, Moの5元素のみが含まれ ていると仮定し，自作プログラムにより SUS304の定量を 行った。FP計算に用いる蛍光X線理論強度計算は, 波長分 散方式の場合, 式 (1) を用いる。エネルギー分散方式の場 合には, 波長 $\lambda$ とエネルギーEの関係 $\lambda=h c / E$ によって横軸 を変換する。ここで, $h$ はプランク定数, $c$ は光速度である。 また $\lambda=h c / E$ の両辺を微分して得られる $d \lambda=-h c d E / E^{2}$ を 用いて ${ }^{19)}$, 白岩一藤野の式中の積分変数を $d E$ に変換した 式 (2) ${ }^{18)}$ を用いた。例えば，白岩一藤野の式に基づき入射 $\mathrm{X}$ 線が $\mathrm{Fe}$ を励起したことにより発生する 1 次の Fe K $\alpha$ 線強 度 $I_{1}(\mathrm{Fe} \mathrm{K} \alpha)$ を求める際, 式 (1) のように積分変数を $\lambda$ と して計算する。本論文での強度計算では, 式 (1) の積分変 数を $E$ に変換した式 (2) により強度を求めた。

$$
I_{1}(\mathrm{Fe} \mathrm{K} \alpha)=\int_{\lambda_{\min }}^{\lambda_{\mathrm{F} \alpha \text { edge }}} Q_{\mathrm{FeK} \alpha}(\lambda) \cdot \frac{I_{0}(\lambda)}{\frac{\mu(\lambda)}{\sin \varphi}+\frac{\mu(\mathrm{FeK} \alpha)}{\sin \psi}} \cdot \frac{1}{\sin \psi} d \lambda
$$

Table 1. K $\alpha$ line energy, full width at half maximum (FWHM), and the ratios of $\mathrm{K} \alpha$ to $\mathrm{K} \beta$ of $\mathrm{Cr}, \mathrm{Mn}, \mathrm{Fe}, \mathrm{Ni}$, and $\mathrm{Mo}$.

\begin{tabular}{cccc}
\hline & K $\alpha$ energy & FWHM & $\mathrm{K} \alpha / \mathrm{K} \beta$ \\
\hline $\mathrm{Cr}$ & $5.42 \mathrm{keV}$ & $136 \mathrm{eV}$ & 0.15 \\
$\mathrm{Mn}$ & 5.91 & 143 & 0.15 \\
$\mathrm{Fe}$ & 7.48 & 150 & 0.15 \\
$\mathrm{Ni}$ & 6.40 & 141 & 0.15 \\
$\mathrm{Mo}$ & 17.43 & 230 & 0.15 \\
\hline
\end{tabular}

$$
I_{1}(\mathrm{Fe} \mathrm{K} \alpha)=h c \int_{E_{\mathrm{Fe} e, d g e}}^{E_{\max }} Q_{\mathrm{FeK} \alpha}(E) \cdot \frac{I_{0}(E)}{\frac{\mu(E)}{\sin \varphi}+\frac{\mu(\mathrm{FeK} \alpha)}{\sin \psi}} \cdot \frac{1}{\sin \psi} \cdot \frac{1}{E^{2}} d E
$$

ここで, $Q$ は $\mu \cdot W \cdot \omega \cdot J \cdot R$ で表される試料の単位重量 あたりの蛍光 $\mathrm{X}$ 線の発生効率である $(\mu$ は質量吸収係数, $W$ は重量分率, $\omega$ は蛍光収率, $J$ はジャンプ比, $R$ はスペクト ル分岐比)。 $I_{0}$ は入射 $X$ 線強度, $\varphi$ および $\psi$ は入射 $X$ 線の試 料への入射角と発生した蛍光X線の取り出し角, $\lambda_{\mathrm{Fe} \text { K } a \text {,edge }}$ は $\mathrm{Fe}$ の $\mathrm{K}$ 吸収端波長, $\lambda_{\text {min }}$ は入射 $\mathrm{X}$ 線の最短波長である。 蛍光収率, ジャンプ比, スペクトル分岐比の值は多くの文 献 ${ }^{20-24)}$ に報告されているが，本研究では島津評論 ${ }^{20)}$ に集積 された1982年のBlokhin ら ${ }^{11)}$ のデータに加えて1969年の McMaster ${ }^{21)} ， 1989$ 年 のde Bore ${ }^{22)}, 2000$ 年 の Chantler ${ }^{23)}$, 2002 年のElam $5^{24)}$ の数值や, 分岐比は Table 1 の実測值, 質量吸収係数はNISTのデータベース ${ }^{25)}$ を用いた。古い文 献を選んだ理由は, 波長分散方式で得られたデータを使う ためである。

含有元素の蛍光 $\mathrm{X}$ 線強度は, $0.02 \mathrm{keV}$ 毎のステップで測 定したエネルギー分散スペクトルを基に, 区分求積法によ り求めた。SUS304とSUS316Lの組成についてはICP発光 分光分析による分析結果を標準值とし, 自作プログラムに よる定量結果と比較した。

なお, ICP発光分光分析は次の条件により行った。 SUS304 は $0.1 \times 100 \times 300 \mathrm{~mm}^{3}$, SUS3 16Lは $0.1 \times 200 \times$ $300 \mathrm{~mm}^{3}$ の板材 (ニラコより購入, 製造者不明) から $40 \times$ $50 \mathrm{~mm}^{2}$ のステンレス片を 3 つ切り取り, 切り取った各ス

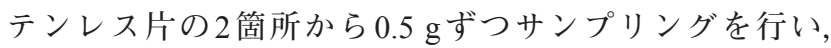
各鋼種に対し6つの試験片を用意した。各試験片はJIS G 1258 ${ }^{26)}$ に従い, $\mathrm{Cr}, \mathrm{Mn}, \mathrm{Ni}, \mathrm{Mo}$ の元素に対して定量分 析を行った。装置にはシーケンシャル型ICP発光分光分析 装置SPS3100HV UV (エスアイアイ・ナノテクノロジー社 製) を用いた。0.5 gの試験片を $25 \mathrm{~mL}$ の混酸 (塩酸 1 : 硝 酸 1 : 水2) により加熱分解後にろ過, 温塩酸および温水に てろ紙洗浄を行った後，100 mLメスフラスコ（IWAKI製 PYREX, 公差 : $20^{\circ} \mathrm{C}$ において $\pm 0.1 \mathrm{~mL}$ ) を用いて定容した ものを ICP 発光分光分析用試料とした。希釈倍率は $\mathrm{Cr}, \mathrm{Ni}$, Mnに対して 20，20，10倍とした。MoはSUS304に添加さ れていないはずなので, 鋼種に応じて希釈倍率を変更し, SUS304については1倍, SUS316Lについては10倍とした。 検量線用溶液はステンレス鋼中の Fe 濃度を $80 \%$ と仮定し, Fe $0.400 \mathrm{~g}$ と定量成分の標準液を適量採取したものを試料 と同様の操作により調製した。各元素に対し, ブランク試 料を含む4点（SUS304のMoについては3点）で検量線を 作成した。検量線用溶液を含む各試料の測定は 5 秒 3 回の 平均值とした。サンプル流量は $1.8 \mathrm{~mL} / \mathrm{min}$ であった。各鋼 種に対して得られた 6 試験片の分析結果から, 各成分濃度 
の平均と標準偏差を算出し定量值とした。この各6試験片 の分析結果によって，それぞれの合金組成は場所によらず 均一とみなせることも確認した。

FP計算の入力パラメータとして用いるX線管スペクト ルとして, Fig.5aに示す配置のようにアクリル板にX線を 45 度入射した際に得られるスペクトル ${ }^{27)}$ ，すなわちアクリ ル板を試料として測定した蛍光X線スペクトル（このスぺ クトルはまた, 自作XRF装置のブランクスペクトルと見做 すこともできる) と，Fig.5bのようにX線管一検出器間に 厚さ $5 \mathrm{~cm}$ のアクリルを挿入し，直線入射した際に得られ るスペクトルを用いた場合，の2種のX線管スペクトルに ついて定量計算を行い精度の比較を行った。Fig.5aの配置 では $30 \mathrm{kV}$ の管電圧, Fig.5bでは $35 \mathrm{kV}$ の管電圧とした。試 料測定は $30 \mathrm{kV}$ なので, $35 \mathrm{kV}$ は, 本来は好ましくないが, $15 \mathrm{keV}$ 以下の $\mathrm{X}$ 線スペクトル成分が減衰するので，あえ て $20 \mathrm{keV}$ 以上のX線スペクトル成分を強調しすぎる場合 のスペクトルとした。Fig.5a および5bに示した実験配置に おける測定スペクトルをFig.6a打よび6bにそれぞれ示す。 Fig.6aはコンプトン散乱によりスペクトルが約 $1 \mathrm{keV}$ 低エ

(a)

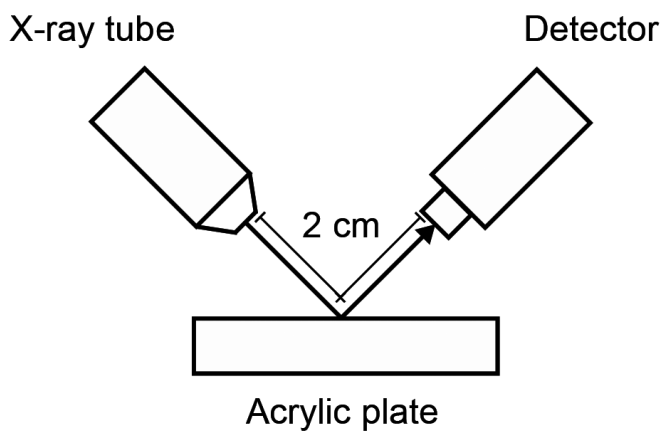

(b)

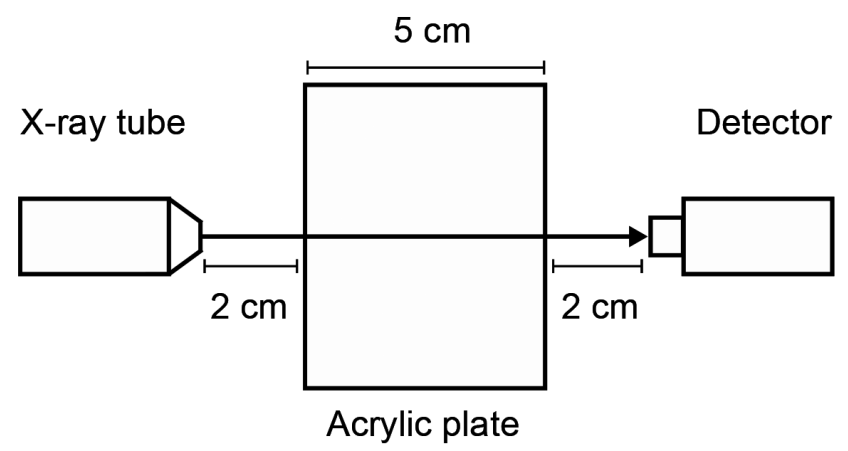

Fig. 5. Setups for XRF measurements of an acrylic plate. Solid arrows represent X-ray paths. The incident X-rays were impinged on the acrylic plate at an angle of (a) 45 and (b) 90 degrees. Measured XRF spectra were used as incident XRF spectra in the FP calculation.
ネルギー側にシフトするが，X線管のスペクトルに近いと みなした。Fig.6bはX線管と検出器を直線上に配置するこ とで，コンプトン散乱されていないスペクトルが得られる が, 検出器の飽和を防ぐために配置したアクリルの影響 で $15 \mathrm{keV}$ 以下に扎いて強度が著しく減衰したスペクトル となった。な拉.6の $3 \mathrm{keV}$ 以下の信号はX線ではなく電 気ノイズによるものであり, $\mathrm{Zr}$ のピークは検出器内部のス リットに起因するが，そのままのスぺクトルをX線管のス ペクトルとみなした。

\section{4. 定量計算結果および考察}

入射 $X$ 線スペクトルを変化させたときの定量計算結果 およびICP発光分光分析による化学分析結果を Table 2 に 示す。Table 2 の残部はFeの濃度である。自作した FP 計算 プログラム ${ }^{18)}$ により，化学分析值と近い計算結果が得ら れた。SUS316Lの測定スペクトルは，装置の幾何学配置や 検出器の感度係数を含めた装置関数を決めるために使つ た。SUS304の初期濃度として適当な濃度值（たとえばFe： $\mathrm{Cr}: \mathrm{Ni}=1: 1: 1)$ を入れても，6，7回計算を繰り返せば, Table 2の数值に収束する。MoについてはICP-AES との定 量值の差が 2 倍となった。本研究ではエネルギー分散型蛍
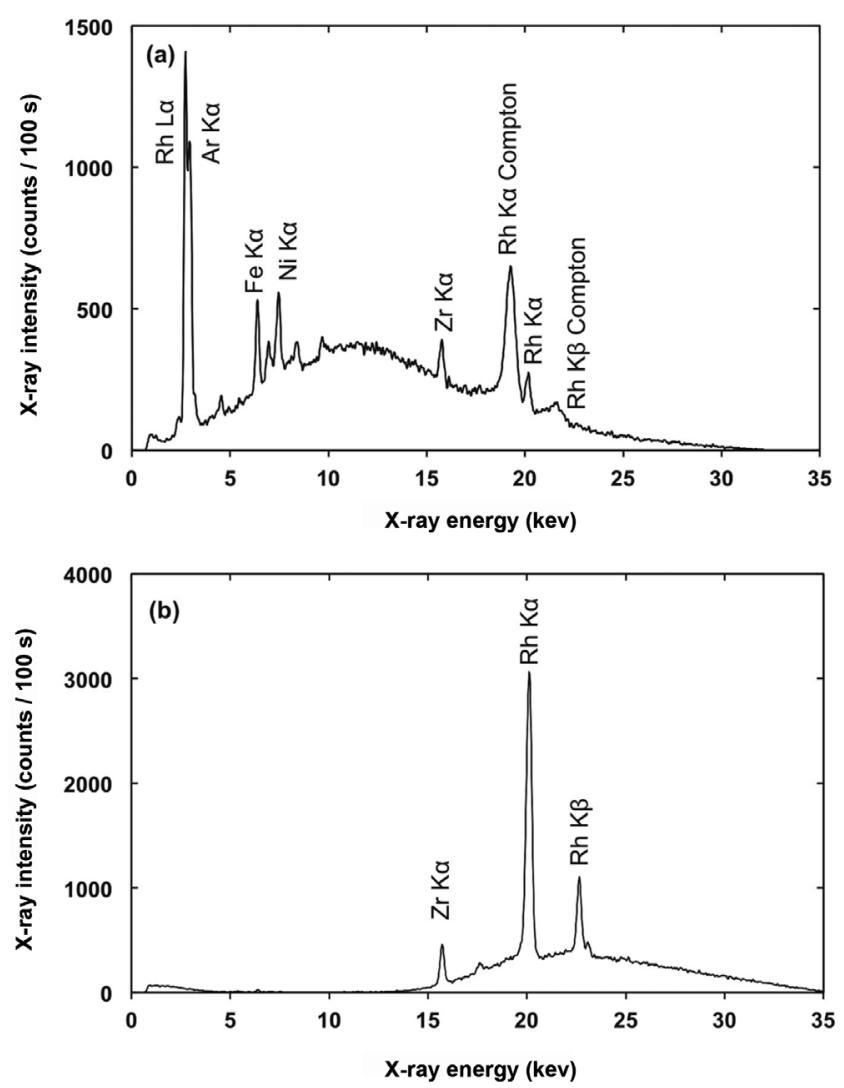

Fig. 6. Measured XRF spectra of an acrylic plate when the incident angles were (a) 45 and (b) 90 degrees. Measurement condition was the same as the one for the measurement of SUS304 and SUS316L. 
光X線スペクトルを用いて定量を行う際の FP強度計算に おいて, 白岩一藤野の式における積分変数を従来の波長か らエネルギーへと変換した式で計算を行っている。式変換 が定量精度へ与える影響を調べるため，式 (2) の $1 / \mathrm{E}^{2}$ の項 を外して計算してみたところ, 感度係数の項が $1 / \mathrm{E}^{2}$ の項を 取り込むため, 実は $1 / \mathrm{E}^{2}$ の項は定量結果には影響しないこ ともわかった ${ }^{28)}$ 。このことから，波長一エネルギーの関係 式に基づく補正が Moの定量精度に影響を与えたのではな いことは確認できた。しかし，定量值に差が生じた原因に ついてはエネルギー分散型蛍光X線装置を用いた測定に 扎いて考慮すべき他の要因についても検討を行う必要が ある。入射 X線強度を変えた場合について, Fig.6bのよう にFig.6aよりも大きく強度が減衰したスペクトルを用いた 場合でも，FP法による定量結果はICP-AES との差で表わ せば，Crに対して $17.86-17.85=0.01$ (Fig.6b) 〜 18.25$17.85=0.40$ (Fig.6a) の正確さで分析できた。15 keV以下 の低エネルギーX線による励起効率の影響を最も受けやす いCrでも，X線管のスペクトルが多少不適切であっても定 量結果には影響しないことがわかった。X線管のスペクト ルがSUS304等の測定条件と異なる Fig.6bのスペクトルの 方がむしろ ICP-AES に近い結果を与えるが，これは様々な 条件が打ち消し合った結果の偶然であろうと思われる。標 準偏差に注目するとXRFの方が ICP-AESより分析精度は 一般に良いが，正確さに関しては，標準試料を用いた ICPAESの方がXRFより信頼できるはずである。

鉄鋼分析では，高精度な分析が要求されるのでEDX方 式は使われず，WDX装置 (多元素同時分析のために最大 40 台のWDX装置が搭載された装置) が用いられている。 共存元素の吸収・励起効果 (マトリックス効果) の代表的

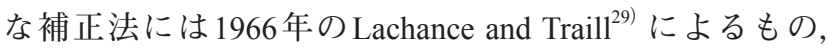
1973 年の de Jongh ${ }^{30)}$ によるものがあって, 測定対象元素の 純物質からの蛍光X線強度を基準として共存元素の効果 を補正する。これらの方法では，基準検量線を 1 次式とし て，測定対象元素が広い組成範囲を有する場合でも有効な 補正方法として用いられており， $\alpha$ 補正法とも呼ばれる。 1982年に鉄と分析元素 (analyte) とを含む合金の測定值を 2 次式で表した基準検量線を基に共存元素効果の補正を行

Table 2. Compositions of $\mathrm{Cr}, \mathrm{Ni}, \mathrm{Mn}$, and Mo in stainless steels measured by the FP method of EDXRF and ICP-AES (mass \%).

\begin{tabular}{ccccc}
\hline XRF or ICP & $\mathrm{Cr}$ & $\mathrm{Ni}$ & $\mathrm{Mn}$ & $\mathrm{Mo}$ \\
\hline $\begin{array}{c}\text { XRF (Fig.6a } \\
\text { (SUS304) }\end{array}$ & $18.25 \pm 0.08$ & $8.09 \pm 0.01$ & $0.795 \pm 0.062$ & $0.380 \pm 0.007$ \\
\hline $\begin{array}{c}\text { XRF (Fig.6b } \\
\text { (SUS304) }\end{array}$ & $17.86 \pm 0.06$ & $8.32 \pm 0.01$ & $0.849 \pm 0.065$ & $0.385 \pm 0.011$ \\
\hline $\begin{array}{l}\text { ICP-AES } \\
\text { (SUS304) }\end{array}$ & $17.85 \pm 0.15$ & $7.96 \pm 0.04$ & $0.826 \pm 0.004$ & $0.185 \pm 0.001$ \\
\hline $\begin{array}{c}\text { ICP-AES } \\
(\text { SUS316L) }\end{array}$ & $17.31 \pm 0.21$ & $12.16 \pm 0.21$ & $0.833 \pm 0.004$ & $2.048 \pm 0.019$ \\
\hline
\end{tabular}

う方法が鉄鋼メーカー各社によって制定され $\mathrm{d}_{\mathrm{j}}$ 法と呼ばれ ている（JIS G 1256）。もともと $\mathrm{d}_{\mathrm{ij}}$ のiはFeを意味したから Lachance-Traill 法 $(\alpha$ 係数法) から鉄鋼分析では分析しない $\mathrm{Fe}$ の項を消去したものが $\mathrm{d}_{j}$ 法である ${ }^{31)}$ 。Ito ${ }^{32)}$ により $\alpha$ 補 正法と $d_{j}$ 法の比較がなされている。

本研究で定量に用いたスペクトルはすべてEDXスペク トルである。EDXの分析精度はWDXに比べて劣る。その 理由として, EDXに用いられている検出器の経時変化によ り短時間の測定であってもスペクトルの再現性が得られな いことが挙げられる。エネルギー補正は 1 日に 1 回以上行 う必要がある。また, SDDのデジタルシグナルプロセッサ で用いられる信号処理アルゴリズムは，メーカーでブラッ クボックス化されており, EDXにおいては上記の $\alpha$ 法や $\mathrm{d}_{\mathrm{j}}$ 法のような定量分析のための補正法を議論することが難し い ${ }^{33)}$ 点などが挙げられる。EDに特有なサムピーク ${ }^{34)} も$ SDD内の数值処理によってその一部を消去したスぺクト ルを表示するSDD検出器も市販されている ${ }^{35)}$ から注意が 必要である。したがってEDXでは，マトリックス補正方法 に関する統一した議論は現在のところ困難である。

本研究では EXCELでFP計算プログラムを自作し, XRF 装置も低電力 $X$ 線管で自作し, 理論強度計算式や入射 $X$ 線 スペクトルなどの入力パラメータを変更した場合の結果 を比較することで, 計算過程と定量精度の関係について 調べた。FP法は第一原理計算だが，定量計算に用いるパラ メータを㛜密に設定しなくても，ある程度の精度で濃度を 求め，ステンレスの種類を同定することができることがわ かった。また, FP法で用いられる従来の蛍光 X線強度計算 式を，エネルギーの2乗で表される項を考慮し補正を行っ たものを用いて定量を行っている。 $\mathrm{d}_{\mathrm{j}}$ 補正法など従来の波 長分散型蛍光X線分析に打いて用いられる補正法を，エネ ルギー分散型蛍光X線分析において適用する場合には，こ のように波長一エネルギーの関係式に基づく補正が必要に なると考えられる。

\section{5. 結論}

エネルギー分散型蛍光X線分析装置を自作し, SUS304 の蛍光X線スペクトルを測定し，ファンダメンタルパラ メータ計算をEXCELで行うプログラムも自作し, やや無 理のある入力パラメータを含めた様々な条件で濃度計算を 行った。装置の感度係数を決めるため, SUS316Lの蛍光 X 線スペクトルを用いた。サンプリング等も含めて定量の正 確さには十分に注意した誘導結合プラズマ発光分光分析を 行い，蛍光X線分析の結果と比較した。

その結果, 以下の 3 点の結論を得た。

(1) ファンダメンタルパラメータ法は, 濃度の第一原理計 算方法であり，絶対濃度值が容易に得られるが，検量 線法ほど正確さはよくない。 
（2）ファンダメンタルパラメータ法の正確さと精度（Crで $18.3 \pm 0.08 \%, \mathrm{Ni}$ で $8.1 \pm 0.01 \%$ ）はエネルギー分散方 式における測定精度の $0.01 \%$ とほほ同等であるため, エネルギー分散型蛍光X線による定量分析に適する。 一方で検量線法は波長分散型蛍光X線による測定精度 に匹敵するため，波長分散型蛍光X線による定量分析 は $\mathrm{d}_{\mathrm{j}}$ 法等の検量線法を用いるべきである。

(3) ファンダメンタルパラメータのデータベースは，あま り正確ではないと言われているが，ファンダメンタル パラメータ自体の改善は, ファンダメンタルパラメー タ法の正確さの改善にはあまり役立たない。X線管の スペクトルなどが少々不正確でも, 重要な部分さえ正 しければ定量結果には影響しない。定量結果に影響す るのは, ファンダメンタルパラメータの正確さよりも, むしろ，重なったピークの分離などの数值処理や，本 研究では扱わなかったが，従来から言われているとお り, 試料表面研磨, 粉末試料の場合には粒径, プレス圧 など試料前処理の効果の方が大きいのではないかと思 われる。

\section{謝辞}

本研究は, 日本鉄鋼協会第 26 回鉄鋼研究振興助成「鉄打 よび鋼の蛍光 X線分析方法の研究」(2017年度〜2018 年度, 代表河合潤）による成果である。京都府中小企業技術セン ター宮内宏哉氏には共同研究のチャンスを提供していただ き感謝する。佐伯正夫氏 (元 新日鐵)には $\mathrm{d}_{\mathrm{j}}$ 法に関する当 時の資料を教えていただいたことに感謝する。

\section{文献}

1 ) H.Friedman and L.S.Birks: NRL-FR-2235, Naval Research Laboratory, Washington, DC, (1944).

2 ) H.Friedman and L.S.Birks: Rev. Sci. Instrum., 19(1948), 323.

3 ) L.S.Birks: Rev. Sci. Instum., 22(1951), 891.

4 ) G.L.Clark: Applied X-Rays, 4th Ed., McGraw-Hill, New York, (1955), 149.

5 ) J.Kawai: Bull. Iron Steel Inst. Jpn., 23(2018), 352 (in Japanese).

6 ) E.Gillam and H.T.Heal: Br. J. Appl. Phys., 3(1952), 353.

7 ) J.Sherman: ASTM Special Publication No.157, ASTM, West
Conshohocken, PA, (1953), 27.

8 ) J.Sherman: Spectrochim. Acta, 7(1955), 283.

9 ) R.M.Rousseau: Open Spectrosc. J., 3(2009), 31. https://doi. org/10.2174/1874383800903010031

10) T.Shiraiwa and N.Fujino: Jpn. J. Appl. Phys., 5(1966), 886.

11) M.A.Blokhin, I.G.Shveitser: Rentgenospektral'nyi spravochnik, Nauka, (1982) (in Russian), and 遠藤敬一訳 : X線分析データ集, 日ソ通信社, (1984).

12) JIS G 1256: 1982, 1997, Iron and Steel - Method for X-ray fluorescence spectrometric analysis (in Japanese).

13) T.Abe, M.Narita and M.Saeki: Adv. X-ray Chem. Anal., Jpn., 17(1986), 143 (in Japanese).

14) K.Kawamura: Tetsu-to-Hagané, 58(1972), 1317 (in Japanese).

15) K.Kawamura: Tetsu-to-Hagané, 60(1974), 1158 (in Japanese).

16) J.Kawai: Adv. X-ray Chem. Anal. Jpn., 43(2012), 475 (in Japanese).

17) T.Sugino, R.Tanaka, J.Kawai, Y.Takenami and J.Kadono: Int. J. PIXE, 27(2017), 87.

18) K.Yamasaki, R.Tanaka and J.Kawai: Adv. X-ray Chem. Anal., Jpn., 49(2018), 201 (in Japanese).

19) A.Iwata, K.Yuge and J.Kawai: X-ray Spectrom., 42(2013), 16.

20) H.Ochi and H.Okashita: Shimadzu Rev., 45(1988), 51 (in Japanese).

21) W.H.McMaster, N.Kerr Del Grande, J.H.Malett and J.H.Hubbell: Report UCRL-50174, Section II, Rev. 1., Lawrence Livermore National Laboratory, Livermore, CA, (1969), 353.

22) D.K.G.de Boer: Spectrochim. Acta, Part B, 44(1989), 1711.

23) C.T.Chantler: J. Phys. Chem. Ref. Data, 29(2000), No.4, 597.

24) W.T.Elam, B.D.Ravel and J.R.Sieber: Radiat. Phys. Chem., 63(2002), 121.

25) NIST: X-Ray Form Factor, Attenuation, and Scattering Tables, (accessed 2018-12-7). https://doi.org/10.18434/T4HS32

26) JIS G 1258: 2014 Iron and Steel - ICP atomic emission spectrometric method (in Japanese).

27) N.Sasaki, K.Okada and J.Kawai: X-Ray Spectrom., 39(2010), 328.

28) K.Yamasaki, R.Tanaka and J.Kawai: CAMP-ISIJ, 31(2017), PS-74, CD-ROM (in Japanese).

29) G.R.Lachance and R.J.Traill: Can. Spectrosc., 11(1966), 43.

30) W.K.de Jongh: X-ray spectrom., 2(1973), 151.

31) 日本鉄鋼業に打ける分析技術 (Analytical Control of Iron and Steel Making in JAPAN) 特別報告書No.34, 日本鉄鋼協会共同 研究会鉄鋼分析部会編，日本鉄鋼協会，東京，(1982)，376，394， 422, 423.

32) M.Ito, S.Sato and M.Narita: X-ray Spectrom., 10(1981), 103.

33) J.Murayama: J. Surf. Anal., 12(2005), 369 (in Japanese).

34) R.Tanaka, K.Yuge, J.Kawai and H.Alawadhi: X-Ray Spectrom., 46(2017), 5.

35) J.Kawai, K.Yoshida and R.Tanaka: Adv. X-Ray Anal., 61(2018), 156. 